\title{
STRATEGI PEMASARAN PRODUK DANA PENSIUN SYARIAH DI DPLK SYARIAH MUAMALAT
}

\author{
Omar Shabri Hanifah \\ omarshabrihanifah@gmail.com \\ (Mahasiswa Program Pasca Sarjana Magister Manajemen Institut Keuangan Perbankan dan \\ Informatika Asia Perbanas)
}

\begin{abstract}
Abstrak
Tujuan dari penelitian ini adalah untuk mengetahui bagaimana strategi pemasaran produk dana pensiun syariah di DPLK Syariah Muamalat dan kendala-kendala apa saja yang dihadapi ketika memasarkan produk dana pensiun syariah kepada masyarakat Indonesia, khususnya kepada kaum muslimin. Berpedoman kepada Al-Qur'an dan Hadist, DPLK Syariah Muamalat diuntungkan sebagai satu-satunya dana pensiun dalam menjalankan bisnisnya berdasarkan prinsip syariah. Metode yang digunakan dalam penelitian ini adalah metode penelitian kualitatif deskriktif, yaitu dengan melakukan observasi ke lokasi penelitian, melakukan wawancara kepada karyawan DPLK Syariah Muamalat dan mengumpulkan datadata dari berbagai sumber yang berhubungan dengan penelitian ini. Diharapkan dari hasil penelitian ini, DPLK Syariah Muamalat bisa memasarkan produknya sesuai dengan keinginan masyarakat Indonesia yang melakukan transaksi dengan aman, nyaman dan berkah serta terhindar dari praktek ribawi. Di samping itu, DPLK Syariah Muamalat dapat berkembang secara signifikan dalam peningkatan jumlah aset dan jumlah peserta.
\end{abstract}

\section{Kata kunci : strategi pemasaran, dana pensiun syariah, DPLK Syariah Muamalat}

\begin{abstract}
The purpose of this research is to find out how the marketing strategy of sharia pension fund products in DPLK Syariah Muamalat and what obstacles are faced when marketing sharia pension fund products to the Indonesian people, especially to Muslims. Guided by the AlQur'an and Hadith, DPLK Syariah Muamalat benefits as the only pension fund in running its business based on sharia principles. The method used in this research is descriptive qualitative research method, namely by observing the research location, conducting interviews with DPLK Syariah Muamalat employees and collecting data from various sources related to this research. It is hoped that from the results of this research, DPLK Syariah Muamalat can market its products according to the wishes of the Indonesian people who carry out transactions in a safe, comfortable and blessed manner and avoid ribawi practices. In addition, DPLK Syariah Muamalat can develop significantly in increasing the number of assets and the number of participants.
\end{abstract}

\section{Keywords : marketing strategy, syaria pension fund, DPLK Syariah Muamalat}

\section{A. Pendahuluan}

Pensiun adalah masa dimana seseorang berhenti bekerja karena telah memasuki usia atau kondisi tertentu, sehingga harus diberhentikan atau atas permintaan sendiri. Seseorang yang sudah pensiun, tidak akan memperoleh pemasukan berupa upah/gaji yang diterima setiap bulannya, namun berhak atas hak yang didapatkannya berupa dana pensiun

14 | Rausyan Fikr. Vol.17 No. 1 Maret-No.2 September 2021. ISSN. 1979-0074 e-ISSN. 9772580594187 
atau pesangon dari perusahaan tempat terakhir bekerja. Dana pensiun akan terus didapatkan oleh pensiunan sampai meninggal dunia, kemudian dilanjutkan kepada ahli waris yang sudah ditunjuk.

Ketika usia masih produktif, banyak pekerja yang kurang peduli akan perencanaan hari tua yang mengakibatkan meningkatnya resiko kesulitan dana ketika sudah berada di masa pensiun. Keberadaan dana pensiun ini sangat penting agar masyarakat dapat terlayani dengan baik, karena :

1. Seseorang yang sudah berhenti bekerja, masih memiliki kebutuhan hidup. Oleh karena itu, dengan mengikuti program pensiun akan tetap memiliki sumber penghasilan untuk kebutuhan hidup.

2. Seseorang yang masih memiliki kemampuan untuk memenuhi biaya hidup, relatif merasa lebih tenang dalam menjalani kehidupannya, sehingga terhindar dari perasaan rendah diri karena tidak bergantung pada orang lain.

3. Jika semua orang hidup dengan tenang, lebih mudah terciptanya harmoni sosial di dalam kehidupan bermasyarakat. Dengan demikian, akan tercipta lingkungan hidup yang nyaman dan relatif terjaga dari permasalahan sosial.

Penetrasi dana pensiun di Indonesia terbilang stagnan dalam lima tahun terakhir. Dalam statistik dana pensiun tahun 2018 yang diterbitkan oleh Otoritas Jasa Keuangan (OJK), penetrasi dana pensiun hanya mencapai $6,01 \%$ atau mencakup 4,64 juta orang dari total tenaga kerja sebanyak 77,14 juta orang. Dari total tenaga kerja tersebut, terbagi dalam kategori berusaha sendiri, berusaha dengan buruh tetap dan buruh/karyawan/pegawai. Melambatnya pertumbuhan penetasi dana pensiun ini disebabkan oleh tiga hal utama. Pertama, banyak perusahaan yang merasa keberatan untuk memikul beban alokasi dana pensiun, sehingga akhirnya program dana pensiun pun dibubarkan. Kedua, dana pensiun yang didirikan oleh perusahaan yang kecil, tentu kemampuannya pun juga sangat kecil untuk tumbuh kembang secara cepat. Ketiga, pemberi kerja lebih mengutamakan iuran ke BPJS/Jamsostek, sehingga dana pensiun terabaikan.

Dana pensiun syariah perlu diperkenalkan secara masif kepada masyarakat agar memahami filosofi perbankan syariah pada umumnya dan dana pensiun syariah pada khususnya beserta adanya dukungan masyarakat Indonesia yang mayoritas beragama muslim. Hal ini bisa menjadi langkah awal agar masyarakat tertarik terhadap program dana pensiun syariah. Lembaga dana pensiun syariah telah mendapat legalitas hukum dengan dikeluarkannya fatwa Dewan Syariah Nasional Majelis Ulama Indonesia Nomor 88/DSN-MUI/XI/2013 tentang pedoman umum penyelenggaraan program pensiun berdasarkan prinsip syariah. Berdasarkan statistik Industri Keuangan Non Bank (IKNB) Syariah pertahun 2018, DPLK Syariah Muamalat merupakan dana pensiun lembaga keuangan yang telah menyediakan produk dana pensiun syariah sejak awal berdirinya pada tanggal 12 September 1997 berdasarkan Surat Keputusan Menteri Keuangan Nomor KEP-485/KM.17/1997. Pada tanggal 23 November 2017, DPLK Syariah Muamalat telah memenuhi persyaratan untuk meyelenggarakan program pensiun berdasarkan prinsip syariah sesuai dengan Peraturan Otoritas Jasa Keuangan (POJK) Nomor 33/POJK.05/2016.

Per-tahun 2019, Nilai Aktiva Bersih DPLK Syariah Muamalat adalah sebesar Rp. 1.269.380.613.324,- dengan jumlah peserta sebanyak 121.810 peserta, terdiri dari peserta korporasi sebanyak 80.502 peserta dan peserta individu sebanyak 41.308 peserta. Dengan tetap mengikuti ketentuan yang berlaku, program dana pensiun di DPLK Syariah

15 | Rausyan Fikr. Vol.17 No. 1 Maret-No.2 September 2021. ISSN. 1979-0074 e-ISSN. 9772580594187 
Muamalat disesuaikan dengan keadaan atau kebutuhan perusahaan sesuai dengan ketentuan Undang- Undang Ketenagakerjaan Nomor 13/2003. Sebagai dana pensiun syariah pertama dan satusatunya di Indonesia, DPLK Syariah Muamalat harus memiliki strategi dalam memasarkan produknya. Akan tetapi, saat ini masih banyak masyarakat Indonesia yang belum memiliki tabungan dana pensiun, khususnya dana pensiun syariah. Hal ini berbanding terbalik dengan jumlah penduduk muslim Indonesia yang terbesar di dunia, yakni mencapai 2,2 miliar jiwa atau sekitar $18 \%$ dari populasi dunia. Oleh karena itu, bagaimana membuat produk dana pensiun syariah yang baik dan berkualitas yang dapat menarik minat masyarakat dalam memberikan manfaat dari produk tersebut serta bagaimana dana pensiun syariah dapat dipasarkan kepada masyarakat, khususnya kepada kaum muslimin yang ingin melakukan transaksi secara halal dan terhindar dari unsur MAGRIB (Maisir, Gharar dan Riba).

Rumusan Masalah dan Tujuan Penelitian Rumusan masalah dalam penelitian ini adalah :

1. Bagaimana strategi pemasaran produk dana pensiun syariah di DPLK Syariah Muamalat?

2. Kendala apa saja yang dihadapi DPLK Syariah Muamalat dalam memasarkan produk dana pensiun syariah ?

Sedangkan tujuan penelitian ini adalah :

1. Untuk mengetahui bagaimana strategi pemasaran produk dana pensiun syariah di DPLK Syariah Muamalat.

2. Untuk mengetahui kendala apa saja yang dihadapi DPLK Syariah Muamalat dalam memasarkan produk dana pensiun syariah.

\section{B. Landasan Teori}

1. Strategi
Strategi adalah pusat dan inti yang khas dari manajemen strategik. Strategi mengacu pada perumusan tugas, tujuan dan sasaran organisasi, strategi kebijakan serta sasaran organisasi. ${ }^{1}$ Strategi merupakan satu kesatuan organisasi rencana terpadu yang diperlukan untuk mencapai tujuan organisasi. Dalam mencapai tujuan organisasi, perlu alternatif strategi yang harus dipertimbangkan dan harus dipilih. Strategi yang dipilih harus diimplementasikan oleh organisasi, kemudian harus dievaluasi terhadap strategi tersebut, karena merupakan suatu alat untuk mencapai suatu tujuan perusahaan. $^{2}$

2. Pemasaran. Menurut Hutama dan Subagio (2014:3), pemasaran adalah serangkaian kegiatan yang dimulai dari proses dalam pembuatan, mengkomunikasikan dan mengenalkan produk serta menawarkan transaksi yang mempunyai nilai bagi konsumen, klien, partner dan masyarakat. Sedangkan Menurut Ali dalam Karnelis (2017:721), pemasaran jasa merupakan proses sosial dimana individu dan kelompok mendapatkan apa yang mereka butuhkan dan inginkan dengan mempertukarkan jasa yang bernilai. $^{3}$ Dilihat dari segi manajemen, manajemen pemasaran merupakan kegiatan penganalisisan, perencanaan, pelaksanaan dan pengendalian program yang disusun untuk membangun keuntungan dari pertukaran pasar berupa barang atau jasa (Assauri, 2013:12). ${ }^{4}$

${ }^{1}$ Agustinus Sri Wahyudi, Manajemen Strategik : Pengantar Proses Berfikir Strategik. (Jakarta : Binarupa Aksara, 1996), h. 35.

${ }^{2}$ Ibid., hal. 37

${ }^{3}$ Sofjan Assauri, Manajemen Pemasaran : Dasar Konsep dan Srategi, (Jakarta : PT. Raja Grafindo Persada, 2008), ha. 93.

${ }^{4}$ Ibid., h. 102.

16 | Rausyan Fikr. Vol.17 No. 1 Maret-No.2 September 2021. ISSN. 1979-0074 e-ISSN. 9772580594187 
3. Strategi Pemasaran. Dari pendapat di atas, dapat disimpulkan bahwa strategi pemasaran adalah proses memberikan arah dalam kaitan dengan segmentasi pasar, identifikasi pasar sasaran, positioning dan bauran pemasaran. Bauran pemasaran (marketing mix) terdiri dari empat elemen yaitu produk, harga, promosi, tempat. Sementara itu, menurut Hurriyati (2010:62), untuk pemasaran jasa perlu bauran pemasaran yang diperluas dengan penambahan tiga unsur, yaitu orang, fasilitas dan proses sehingga menjadi $7 \mathrm{P}$. Ketujuh elemen tersebut saling berhubungan satu sama lainnya dan dapat dikombinasikan sesuai dengan lingkungan, baik di dalam maupun di luar perusahaan agar tujuan perusahaan tercapai. (Kotler, 2009:6). ${ }^{5}$

4. Dana Pensiun Syariah. Dana pensiun adalah badan hukum yang mengelola dan menjalankan program manfaat pensiun dengan tujuan untuk memberikan kesejahteraan kepada para karyawan di perusahaan, terutama bagi yang sudah memasuki usia pensiun. ${ }^{6}$

Dana pensiun terdiri dari dua jenis, yaitu $:^{7}$

1. Dana Pensiun Pemberi Kerja (DPPK), yaitu dana pensiun yang dibentuk oleh orang atau badan yang memperkerjakan karyawan selaku pendiri untuk menyelenggarakan Program Pensiun Manfaat Pasti (PPMP) atau Program Pensiun Iuran Pasti (PPIP) bagi kepentingan sebagian atau seluruh karyawannya sebagai peserta dan yang menimbulkan kewajiban terhadap pemberi kerja.

5 Muhammad Firdaus, Dasar \& Strategi Pemasaran Syariah, (Jakarta : Renaisan, 2005), h. 45.

6 Undang-Undang Dana Pensiun Nomor 11 Tahun 1992, Dana Pensiun, 20 April 1992, Lembaran Negara Republik Indonesia Tahun 1992 Nomor 37, Jakarta.

$$
{ }^{7} \text { Ibid. }
$$

2. Dana Pensiun Lembaga Keuangan (DPLK), yaitu dana pensiun yang dibentuk oleh bank atau asuransi jiwa untuk menyelenggarakan Program Pensiun Iuran Pasti (PPIP) bagi perorangan, baik karyawan maupun pekerja mandiri yang terpisah dari Dana Pensiun Pemberi Kerja bagi karyawan bank atau asuransi jiwa yang bersangkutan.

Sedangkan program dana pensiun terdiri dari dua jenis, yaitu : ${ }^{8}$

1. Program Pensiun Manfaat Pasti (PPMP), yaitu program pensiun yang menetapkan rumus tertentu atas manfaat yang akan diterima oleh peserta ketika sudah mencapai usia pensiun. Dalam program pensiun ini, perusahaan dana pensiun umumnya akan mempertimbangkan masa kerja dan besaran gaji atau penghasilan karyawan.

2. Program Pensiun Iuran Pasti (PPIP), yaitu program pensiun yang iurannya telah ditetapkan sesuai Peraturan Dana Pensiun (PDP) dengan manfaat berupa keseluruhan/akumulasi iuran beserta hasil pengembangan atau investasi sesuai yang dipilih oleh peserta.

Tabel.1

Perbedaan Program Pensiun Manfaat Pasti (PPMP) dan Program Pensiun Iuran Pasti (PPIP)

\begin{tabular}{|l|l|l|}
\hline \multirow{5}{*}{ Aspek } & $\begin{array}{l}\text { Program } \\
\text { Pensiun } \\
\text { Manfaat } \\
\text { Pasti } \\
\text { (PPMP) }\end{array}$ & $\begin{array}{l}\text { Program } \\
\text { Pensiun } \\
\text { Iuran Pasti } \\
\text { (PPIP) }\end{array}$ \\
\hline \multirow{3}{*}{ Jenis } & $\cdot$ Dana & $\cdot$ Dana \\
& Pensiun & Pensiun \\
& Pemberi & Pemberi \\
& Kerja \\
& Kerja & (DPPK) \\
& & Dana \\
\hline
\end{tabular}

${ }^{8}$ Ibid.

17 | Rausyan Fikr. Vol.17 No. 1 Maret-No.2 September 2021. ISSN. 1979-0074 e-ISSN. 9772580594187 


\begin{tabular}{|c|c|c|}
\hline & & $\begin{array}{l}\text { Pensiun } \\
\text { Lembaga } \\
\text { Keuangan } \\
\text { (DPLK) }\end{array}$ \\
\hline $\begin{array}{l}\text { Manfaat } \\
\text { Pensiun }\end{array}$ & $\begin{array}{l}\text { - Nilai } \\
\text { manfaat } \\
\text { pensiun } \\
\text { sudah } \\
\text { pasti, } \\
\text { dihitung } \\
\text { dengan } \\
\text { rumus } \\
\text { tertentu } \\
\text { sesuai } \\
\text { Peraturan } \\
\text { Dana } \\
\text { Pensiun. } \\
\text { Tidak ada } \\
\text { risiko bagi } \\
\text { peserta. }\end{array}$ & $\begin{array}{l}\text { Nilai } \\
\text { manfaat } \\
\text { pensiun } \\
\text { tidak pasti, } \\
\text { tergantung } \\
\text { pada } \\
\text { besaran } \\
\text { iuran dan } \\
\text { hasil } \\
\text { pengemban } \\
\text { gan atau } \\
\text { investasi. } \\
\text { Ada risiko } \\
\text { bagi } \\
\text { peserta. }\end{array}$ \\
\hline Iuran & $\begin{array}{l}\text { - Besaran } \\
\text { iuran bagi } \\
\text { peserta } \\
\text { sudah } \\
\text { pasti. } \\
\text { · Besaran } \\
\text { iuran bagi } \\
\text { pemberi } \\
\text { kerja tidak } \\
\text { pasti } \\
\text { (fluktuatif } \\
\text { ). } \\
\text { - Terdapat } \\
\text { risiko } \\
\text { pendanaan } \\
\text { bagi } \\
\text { pemberi } \\
\text { kerja. }\end{array}$ & $\begin{array}{l}\text { - Besaran } \\
\text { iuran bagi } \\
\text { peserta } \\
\text { sudah pasti. } \\
\text { - Besaran } \\
\text { iuran bagi } \\
\text { pemberi } \\
\text { kerja sudah } \\
\text { pasti. } \\
\text { - Tidak ada } \\
\text { risiko } \\
\text { pendanaan } \\
\text { bagi } \\
\text { pemberi } \\
\text { kerja. }\end{array}$ \\
\hline $\begin{array}{l}\text { Risiko } \\
\text { Pendanaa }\end{array}$ & $\begin{array}{l}\text { Pemberi } \\
\text { Kerja }\end{array}$ & - Peserta \\
\hline
\end{tabular}

\begin{tabular}{|l|l|l|}
\hline $\begin{array}{l}\mathrm{n} / \\
\text { Investasi }\end{array}$ & & \\
\hline $\begin{array}{l}\text { Administ } \\
\text { rasi Dana }\end{array}$ & $\cdot \begin{array}{l}\text { Bersifat } \\
\text { Kelompok }\end{array}$ & $\cdot \begin{array}{l}\text { Bersifat } \\
\text { Individual }\end{array}$ \\
\hline
\end{tabular}

Dana pensiun syariah adalah dana pensiun yang menyelenggarakan program pensiun berdasarkan prinsip syariah dan dapat dilakukan oleh pemberi kerja atau dengan menyerahkan kepada lembaga keuangan yang menawarkan program dana pensiun syariah. ${ }^{9}$

Tabel.2

Perbedaan Dana Pensiun Konvensional dan Dana Pensiun Syariah

\begin{tabular}{|l|l|l|}
\hline spek & $\begin{array}{l}\text { Dana } \\
\text { Pensiun } \\
\text { Konvension } \\
\text { al }\end{array}$ & $\begin{array}{l}\text { Dana Pensiun } \\
\text { Syariah }\end{array}$ \\
\hline Investasi & $\begin{array}{l}\text { Instrumen } \\
\text { investasi } \\
\text { bebas, baik } \\
\text { di pasar } \\
\text { uang dan } \\
\text { pasar } \\
\text { modal. }\end{array}$ & $\begin{array}{l}\text { Hanya pada } \\
\text { instrumen } \\
\text { investasi } \\
\text { syariah saja, } \\
\text { baik di pasar } \\
\text { uang dan } \\
\text { pasar modal. }\end{array}$ \\
\hline $\begin{array}{l}\text { Pengemb } \\
\text { angan } \\
\text { Dana }\end{array}$ & $\begin{array}{l}\text { Menggunak } \\
\text { an sistem } \\
\text { bunga. }\end{array}$ & $\begin{array}{l}\text { Menggunakan } \\
\text { sistem bagi } \\
\text { hasil/ profit } \\
\text { sharing/ } \\
\text { mudharabah. }\end{array}$ \\
\hline $\begin{array}{l}\text { Manfaat } \\
\text { Pensiun }\end{array}$ & $\begin{array}{l}\text { Sesuai } \\
\text { dengan } \\
\text { hasil } \\
\text { investasi } \\
\text { non-syariah. }\end{array}$ & $\begin{array}{l}\text { Sesuai dengan } \\
\text { hasil investasi } \\
\text { syariah. }\end{array}$ \\
\hline
\end{tabular}

${ }^{9}$ Fatwa Dewan Syariah Nasional Nomor 88/DSN-MUI/XI/2013, Pedoman Umum Penyelenggaraan Progam Dana Pensiun Syariah, 15 November 2013, Dewan Syariah Nasional Majelis Ulama Indonesia, Jakarta.

18 | Rausyan Fikr. Vol.17 No. 1 Maret-No.2 September 2021. ISSN. 1979-0074 e-ISSN. 9772580594187 
Dalam syariah, akad berfungsi untuk mendapatkan kesepakatan dari kedua belah pihak. ${ }^{10}$ Dalam menjalankan roda perekonomiannya, DPLK Syariah Muamalat memakai dua akad kepada peserta, yakni :

1. Hibah bi Syath, merupakan akad yang dilakukan dengan sistem hibah apabila syarat dan perjanjian sudah dipenuhi dan sesuai dengan peraturan yang ada.

2. Wakalah bil Ujrah, merupakan pemberian kuasa dari peserta kepada perusahaan untuk dapat mengelola dana peserta dengan imbalan pemberian ujrah (fee).

\section{Metode Penelitian}

Penelitian ini menggunakan metode penelitian kualitatif deskriktif, yaitu penelitian yang dilakukan untuk memberikan gambaran dan menjelaskan tentang gejala, keadaan atau peristiwa tertentu berdasarkan fakta-fakta. ${ }^{11}$ Tujuannya adalah untuk menjawab pertanyaan yang ada pada rumusan masalah penelitian secara komperehensif dan mendalam mengenai strategi pemasaran produk dana pensiun syariah di DPLK Syariah Muamalat serta kendala apa saja yang dihadapi dalam memasarkan produk dana pensiun syariah. Selain itu, tujuan penelitian ini juga untuk memperoleh data yang mendalam serta mengungkapkan fakta yang terjadi pada objek penelitian, yaitu strategi pemasaran produk dana pensiun syariah.

Sumber data yang digunakan dalam penelitian ini adalah :

1. Data primer, yaitu data yang bersumber dari hasil wawancara dengan

${ }^{10}$ A. Soemitra, Bank dan Lembaga Keuangan Syariah, (Jakarta : Kencana, 2009), h. 152.

${ }^{11}$ M. Yusuf, (2014). Metode Penelitian : Kuantitatif, Kualitatif dan Penelitian Gabungan, (Jakarta : Prenadamedia Grup, 2014), h. 78. narasumber yang ada di DPLK Syariah Muamalat.

2. Data sekunder, yaitu data yang diperoleh dengan mengumpulkan dokumen-dokumen yang berkaitan dengan penelitian ini, seperti profil perusahaan, laporan keuangan perusahaan, laporan kinerja perusahaan dan data-data penunjang tambahan lainnya yang diperoleh dari buku, media cetak, media elektronik dan jurnal.

Teknik pengumpulan data yang diperlukan dalam penelitian ini adalah :

1. Observasi, yaitu peninjauan langsung ke objek/ lokasi penelitian untuk melakukan pengamatan dan pencatatan terhadap strategi pemasaran produk dana pensiun syariah. Adapun objek penelitian ini adalah Dana Pensiun Lembaga Keuangan (DPLK) Syariah Muamalat yang berada di Gedung Muamalat Tower Lantai 12, Jl. Prof. Dr. Satrio, Kav. 18, Kuningan, Jakarta Selatan.

2. Wawancara, yaitu melakukan percakapan langsung terhadap narasumber untuk mendapatkan informasi yang diperlukan dalam penelitian ini. Adapun narasumber dalam wawancara ini sebanyak 3 (tiga) orang karyawan DPLK Syariah Muamalat, terdiri dari Pelaksana Tugas Pengurus, Koordinator Pemasaran dan Staff Pemasaran.

3. Dokumentasi, yaitu mengumpulkan data yang diperlukan berupa catatan-catatan penting yang dibutuhkan dalam penelitian ini, sehingga diperoleh data yang lengkap, akurat, sah dan bukan berdasarkan perkiraan.

\section{Hasil Dan Pembahasan}

Strategi Pemasaran Produk Dana Pensiun Syariah. Sebagai lembaga keuangan non bank, DPLK Syariah Muamalat menjalankan bisnisnya berdasarkan prinsip syariah serta tidak 
lepas dari persaingan antar lembaga keuangan non bank lainnya. Semakin tingginya minat masyarakat terhadap produk dana pensiun syariah, DPLK Syariah Muamalat melakukan pengembangan produk, sehingga memiliki daya tarik dan nilai jual yang dapat memberikan pengaruh kepada peserta ataupun calon peserta. Untuk meningkatkan pertumbuhan dan perkembangan bisnis DPLK Syariah Muamalat, langkah-langkah yang diambil dalam memasarkan produk dana pensiun syariah ini antara lain :

1. Segmentasi Pasar. DPLK Syariah Muamalat membagi beberapa jenis segmentasi pasar sesuai dengan kriterianya agar dapat memudahkan dalam menentukan sasaran peserta. Hal ini karena pasaran suatu produk atau jasa mempunyai banyak perbedaan, terutama pada kebutuhan, keinginan dan daya beli. Dengan melakukan segmentasi pasar, perusahaan akan lebih mudah melayani berbagai kebutuhan dan keinginan pasar tersebut. Ttiga cara yang dilakukan DPLK Syariah Muamalat dalam menentukan segmentasi pasar, antara lain :

a. Dari segi daerah. DPLK Syariah Muamalat memfokuskan pemasarannya di wilayah Jakarta, Bogor, Depok, Tangerang dan Bekasi (JABODETABEK). Sedangkan untuk luar wilayah JABODETABEK, DPLK Syariah Muamalat bekerjasama dengan tim marketing Bank Muamalat Indonesia yang tersebar di seluruh Indonesia untuk memasarkan produk dana pensiun syariah.

b. Dari segi usia. Syarat menjadi peserta DPLK Syariah Muamalat adalah minimal berusia 18 tahun atau sudah menikah dengan melampirkan fotokopi identitas pribadi (KTP/SIM/ PASPOR/KITAS). c. Dari segi pekerja. DPLK Syariah Muamalat tidak membedakan status pekerjaan peserta, baik karyawan swasta, pegawai negeri sipil, pengusaha, pedagang atau ahli profesi lainnya (pengacara, dokter, artis, pengajar dan lain sebagainya) selama yang bersangkutan masih memiliki penghasilan.

2. Targeting atau Menetapkan Sasaran Pasar. Setelah melakukan segmentasi pasar, selanjutnya DPLK Syariah Muamalat harus menentukan sasaran pasar dengan cara mengevaluasi keaktifan setiap segmen, memilih salah satu dari segmen pasar atau lebih untuk dilayani serta menetapkan pasar sasaran dengan mengembangkan ukuran-ukuran dan daya tarik segmen sesuai dengan sasaran yang diinginkan. Target sasaran DPLK Syariah Muamalat adalah seluruh masyarakat Indonesia tanpa membedakan suku, ras, daerah dan status sosial.

3. Positioning atau Menentukan Pasar. Sesuai dengan prinsip syariah, DPLK Syariah Muamalat memposisikan dirinya berbeda dengan DPLK lainnya, sehingga terbuka bagi Peserta yang benar-benar ingin terhindar dari praktek maisir, gharar dan riba (MAGHRIB).

Strategi pemasaran DPLK Syariah Muamalat dapat dilakukan dengan berbagai macam cara, antara lain :

1. Strategi Produk. Dalam mengembangkan produknya, strategi yang dilakukan DPLK Syariah Muamalat adalah :

a. Membuat Logo dan Motto. Logo DPLK Syariah Muamalat adalah "Din" yang artinya agama. Logo tersebut digunakan karena DPLK Syariah Muamalat adalah lembaga keuangan yang menjalankan kegiatan usahanya berdasarkan prinsip syariah dan dalam pengelolaannya selalu berpedoman pada ajaran Alqur'an dan Hadits. Sedangkan motto DPLK 
Syariah Muamalat adalah "Masa Muda Berencana, Hari Tua Sejahtera". b. Menciptakan Merk. Merk produk yang digunakan DPLK Syariah Muamalat adalah Pensiun Terencana Muamalat untuk Program Pensiun Iuran Pasti (PPIP) dan Pensiun untuk Pesangon Terencana Muamalat untuk Program Pensiun Untuk Kompensasi Pesangon (PPUKP). Dengan menggunakan merk ini, diharapkan dapat menarik minat masyarakat Indonesia pada umumnya dan kaum muslimin pada khususnya untuk menjadi peserta DPLK Syariah Muamalat.

c. Menciptakan Kemasan. Kemasan produk yang digunakan DPLK Syariah Muamalat lebih kepada pemberian jasa pelayanan dalam bentuk penawaran produk untuk dapat menarik minat calon peserta.

2. Strategi Promosi. Dalam memasarkan produknya, strategi promosi yang digunakan DPLK Syariah Muamalat adalah : sebagai berikut :

a. Periklanan (advertising)

Periklanan yang digunakan DPLK Syariah Muamalat melalui :

- Media cetak, berupa surat kabar, majalah, brosur, spanduk dan lain sebagainya.

- Media Elektronik, berupa website yang dapat diakses selama 24 jam dimanapun peserta ataupun calon peserta berada melalui www.dplksyariahmuamalat.co.id.

b. Penjualan Pribadi (Personal Selling). DPLK Syariah Muamalat menerjunkan tim marketingnya dalam memasarkan produk dana pensiun, baik Program Pensiun Iuran Pasti (PPIP) maupun Program Pensiun Untuk Kompensasi Pesangon (PPUKP). Tata cara pelaksanaan adalah dimana tim marketing mendatangi peserta ataupun calon peserta, kemudian menjelaskan secara rinci dan jelas tentang produk dana pension yang ada di DPLK Syariah Muamalat. Selain itu, DPLK Syariah Muamalat juga melakukan kerjasama dengan tim marketing Bank Muamalat Indonesia yang berada kantor cabang seluruh Indonesia, kemudian melakukan cross selling antara produk yang ada di Bank Muamalat Indonesia dengan produk yang ada di DPLK Syariah Muamalat. Sedangkan untuk peserta korporasi, DPLK Syariah Muamalat menunjuk PIC (Person In Charge) di masingmasing kantor cabang Bank Muamalat Indonesia untuk memasarkan produk dana pensiun syariah. PIC tersebut bertugas untuk memasarkan/ menawarkan produk dana pensiun syariah ke berbagai perusahaan, perguruan tinggi, yayasan, koperasi dan lain sebagainya kemudian melakukan sosialisasi dengan cara melakukan presentasi produk.

c. Publisitas. Kegiatan publisitas yang diakukan DPLK Syariah Muamalat yaitu dengan cara mengundang peserta ataupun calon peserta untuk melakukan sosialisasi dengan tujuan agar dapat menambah wawasan tentang produk dana pensiun syariah serta dapat merealisasikan produk tersebut kepada yang lainnya.

3. Strategi Harga. Penetapan strategi harga di DPLK Syariah Muamalat dilihat dari pengembalian modal, yaitu dengan penerapan bagi hasil sesuai dengan paket investasi yang dipilih oleh peserta. DPLK Syariah Muamalat mempunyai ragam pilihan paket investasi yang dapat dipilih dan diubah secara fleksibel, antara lain :

a. Paket $A$, terdiri dari 1 (satu) macam instrumen, yakni Deposito Syariah $(100 \%)$. 
b. Paket $B$, terdiri dari 2 (dua) macam instrumen, yakni Deposito Syariah (maksimal 100\%) dan atau Sukuk, Surat Berharga Syariah Negara (maksimal 80\%).

c. Paket $C$, terdiri dari 3 (tiga) macam instrumen, yakni Deposito Syariah (maksimal 100\%) dan atau Reksadana Syariah (maksimal 80\%) dan atau Saham Syariah (maksimal 50\%).

Tabel.3

Hasil Investasi DPLK Syariah Muamalat Periode 2013 - 2019

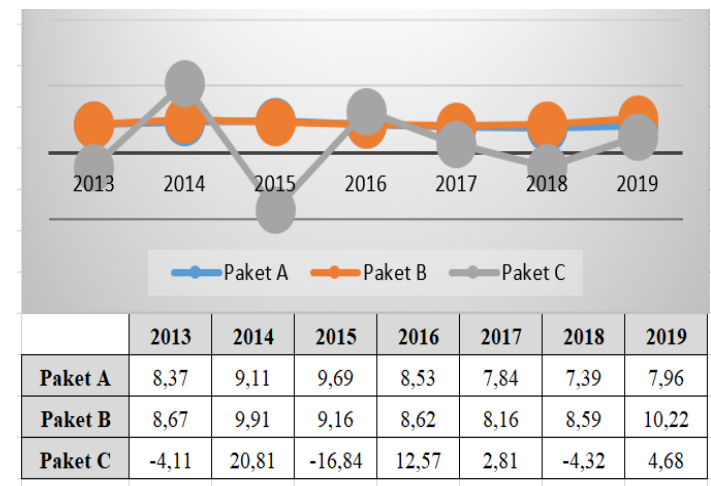

4. Strategi Distribusi. Saluran distribusi merupakan salah satu daya tarik tersendiri bagi peserta maupun calon peserta untuk memilih suatu lembaga keuangan. Oleh karena itu, saluran distribusi produk dana pensiun syariah di DPLK Syariah Muamalat diwakilkan oleh setiap kantor cabang Bank Muamalat Indonesia dengan menggunakan bauran pemasaran yang terdiri dari $4 \mathrm{P}$ (product, price, place, promotion). Selain bauran pemasaran tersebut, terdapat strategi pelayanan atau service, sebab apabila produk dana pensiun syariah bermutu dan bagus, akan tetapi jika pelayanannya kurang bagus, maka konsumen merasa tidak akan puas.

Kendala DPLK Syariah Muamalat dalam memasarkan produk dana pensiun syariah
Perkembangan industri lembaga keuangan syariah di Indonesia diakui sebagai batu loncatan dengan mulai menggeliatnya kembali aktifitas perekonomian berbasis sistem ekonomi Islam yang kemudian diikuti dengan tumbuh berkembangnya instrument sistem ekonomi syariah, seperti asuransi, perbankan, pegadaian, pasar modal dan lain sebagainya. Menurut data dari Otoritas Jasa Keuangan (OJK), ekspansi perbankan syariah mulai membuahkan hasil yang dibuktikan dari pangsa industri perbankan syariah di Indonesia yang sudah menembus $6,01 \%$ per Oktober 2019. Hal ini membuktikan bahwa sistem perekonomian syariah disambut baik oleh sebagian masyarakat Indonesia. Maraknya sambutan pasar terhadap jasa yang ditawarkan lembaga keuangan syariah, telah menimbulkan optimisme para pelaku bisnis dan ekonomi, termasuk pemerintah untuk menggarap segmen ini.

Keberpihakan pemerintah untuk mendukung sistem ekonomi syariah mulai dirasakan, meskipun masih sedikit dibandingkan dengan ekonomi konvensional. Untuk merespons perkembangan aktifitas perbankan syariah serta mendorong laju ekspansi usahanya, pada tahun 2006 Bank Indonesia telah mengeluarkan regulasi baru tentang kegiatan bank umum konvensional yang boleh melaksanakan kegiatan usaha penghimpunan dana nasabah berdasarkan prinsip syariah, yang dikenal dengan sebutan "office channeling system". Meskipun demikian, masih banyak juga masyarakat, khususnya kaum muslimin yang masih melakukan transaksi di perbankan konvensional. Hal ini terjadi karena kurangnya ilmu pengetahuan masyarakat tentang produk maupun jasa perbankan syariah, sehingga masyarakat enggan memanfaatkan produk yang dikeluarkan oleh industri keuangan syariah. 
Begitu pula dengan DPLK Syariah Muamalat sebagai dana pensiun syariah yang ada di Indonesia dalam melakukan kegiatan pemasaran produknya, tentu seringkali menghadapi beberapa kendala, antara lain :

1. Kurang dikenalnya tentang produk dana pensiun syariah dibandingkan dengan produk dana pensiun konvensional;

2. Kurangnya sosialisasi kepada masyarakat tentang konsep, mekanisme, urgensi bahkan keberadaan industri perbankan syariah, khususnya dana pensiun syariah;

3. Masih belum pahamnya masyarakat mengenai fitur-fitur di dana pensiun syariah, seperti aplikasi dan produknya;

4. Masih terdapatnya kekurangan di dalam produk dana pensiun syariah dibandingkan dengan dana pensiun konvensional.

Untuk mengatasi berbagai kendala tersebut, upaya yang dilakukan DPLK Syariah Muamalat agar tetap bertahan dan dapat bersaing dengan dana pensiun konvensional adalah sebagai berikut :

1. Menciptakan keseimbangan yang adil di antara stakeholder melalui bermacammacam peraturan, baik informal maupun formal.

2. Mengontrol dana pensiun syariah dengan biaya yang relatif murah.

3. Menciptakan kesejahteraan pegawai dan peserta dan mendorong penyusunan pedoman tata kelola yang baik di lingkungan dana pensiun sekaligus memberikan acuan kepada pendiri, pemberi kerja, pengurus dan pengawas dana pensiun.

Menawarkan kepada peserta yang melakukan klaim pencairan manfaat pensiun dan ingin berzakat, terdapat fasilitas zakat dana pensiun dengan cara memotong maksimal 5\% dari jumlah manfaat pensiun yang didapatkan oleh peserta. Zakat tersebut kemudian disalurkan kepada amil zakat yang sudah bekerjasama dengan DPLK Syariah Muamalat untuk diserahkan kepada yang membutuhkan.

\section{E. Kesimpulan}

Berdasarkan hasil penelitian mengenai strategi pemasaran produk dana pensiun syariah di DPLK Syariah Muamalat, kesimpulan yang dapat diambil adalah sebagai berikut :

1. Strategi pemasaran yang dilakukan DPLK Syariah Muamalat dalam memasarkan produk dana pensiun syariah menggunakan 3 (tiga) strategi, yaitu :

a.Strategi produk, dapat dilakukan dengan membuat logo dan motto, menciptakan merek dan menciptakan kemasan.

b.Strategi promosi, dapat dilakukan dengan periklanan (advertising) melalui media cetak dan media elektronik, penjualan pribadi (personal selling) dan kegiatan publisitas.

c.Strategi harga, dapat dilakukan dengan pengembalian modal berupa penerapan bagi hasil sesuai dengan paket investasi yang dipilih oleh peserta, terdiri dari 3 (tiga) macam paket investasi, antara lain :

- Paket A, terdiri dari Deposito Syariah (maksimal 100\%);

- Paket B, terdiri dari Deposito Syariah (maksimal 100\%) dan atau Sukuk, Surat Berharga Syariah Negara (maksimal 80\%); dan

- Paket $C$, terdiri dari Deposito Syariah (maksimal 100\%) dan atau Reksadana Syariah (maksimal 80\%) dan atau Saham Syariah (maksimal $50 \%$ ).

d.Strategi distribusi, dapat dilakukan dengan cross selling dengan seluruh kantor cabang Bank Muamalat Indonesia dengan menerapkan bauran pemasaran yang terdiri $4 \mathrm{P}$ (Product, 
price, place, promotion). Di samping itu, terdapat strategi pelayanan atau service untuk menjaga produk agar tetap bermutu dan pelayanan terhadap konsumen menjadi puas.

2. Beberapa kendala yang dihadapi DPLK Syariah Muamalat dalam memasarkan produk dana pensiun syariah dan beberapa upaya untuk mengatasi kendala tersebut adalah sebagai berikut : a. Kendala

- Kurang dikenalnya tentang produk dana pensiun syariah dibandingkan dengan produk dana pensiun konvensional;

- Kurangnya sosialisasi kepada masyarakat tentang konsep, mekanisme, urgensi bahkan keberadaan industri perbankan syariah, khususnya dana pensiun syariah;

- Masih belum pahamnya masyarakat mengenai fitur-fitur di dana pensiun syariah, seperti aplikasi dan produknya;

- Masih terdapatnya kekurangan di dalam produk dana pensiun syariah dibandingkan dengan dana pensiun konvensional.

b. Upaya

- Menciptakan keseimbangan yang adil di antara stakeholder melalui bermacam-macam peraturan, baik informal maupun formal.

- Mengontrol dana pensiun syariah dengan biaya yang relatif murah.

- Menciptakan kesejahteraan pegawai dan peserta dan mendorong penyusunan pedoman tata kelola yang baik di lingkungan dana pensiun sekaligus memberikan acuan kepada pendiri, pemberi kerja, pengurus dan pengawas dana pensiun.

Menawarkan kepada peserta yang melakukan klaim pencairan manfaat pensiun dan ingin berzakat, terdapat fasilitas zakat dana pensiun dengan cara memotong maksimal 5\% dari jumlah manfaat pensiun yang didapatkan oleh peserta. Zakat tersebut kemudian disalurkan kepada amil zakat yang sudah bekerjasama dengan DPLK Syariah Muamalat untuk diserahkan kepada yang membutuhkan.

\section{DAFTAR PUSTAKA}

Assauri, Sofjan. (2008). Manajemen Pemasaran: Dasar Konsep dan Srategi. Jakarta: PT. Raja Grafindo Persada.

Firdaus, Muhammad. (2005). Dasar \& Strategi Pemasaran Syariah. Jakarta: Renaisan.

Fatwa Dewan Syariah Nasional Nomor 88/DSN-MUI/XI/2013. (2013).

Pedoman Umum Penyelenggaraan Progam Dana Pensiun Syariah. Jakarta: Dewan Syariah Nasional Majelis Ulama Indonesia.

Moelong, L. J. (2009). Metode Penelitian Kualitatif. Bandung : PT Remaja Rosdakarya.

Soemitra, A. (2009). Bank dan Lembaga Keuangan Syariah. Jakarta: Kencana.

Sri Wahyudi, Agustinus. (1996). Manajemen Strategik: Pengantar Proses Berfikir Strategik. Jakarta: Binarupa Aksara.

Undang-Undang Dana Pensiun Nomor 11 Tahun 1992. (1992). Dana Pensiun. Jakarta: Lembaran Negara Republik Indonesia Tahun 1992 Nomor 37.

Yusuf, M. (2014). Metode Penelitian : Kuantitatif, Kualitatif dan Penelitian Gabungan. Jakarta: Prenadamedia Grup. 
2 | Rausyan Fikr. Vol.17 No. 1 Maret-No.2 September 2021. ISSN. 1979-0074 e-ISSN. 9772580594187 